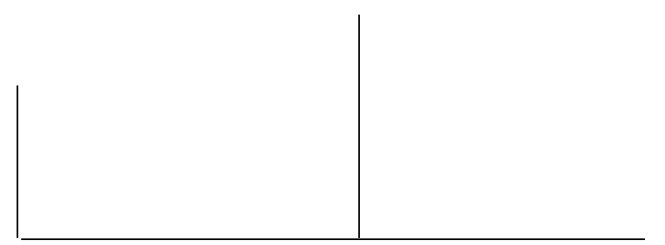

Rev. Latinoam. Psicopat. Fund., VI, 4, 80-101

\title{
Transferência e criatividade no tempo da análise*
}

\author{
Zeferino Rocha
}

\begin{abstract}
O objetivo do artigo é refletir sobre a dimensão criativa da Transferência no Tempo da Análise. Para isso, o autor situa a temporalidade psicanalítica no contexto da visão filosófica do tempo e a articula, de modo particular, com a noção de temporalidade defendida por Heidegger na Analítica Existencial; depois, relaciona a transferência com a interpretação psicanalítica, ressaltando o poder criativo da palavra que, por meio da dialética do dizer e do escutar, está na base da relação transferencial e contratransferencial vividas na análise.
\end{abstract}

Palavras-chave: Transferência, interpretação analítica e poder criativo da palavra

* Este trabalho, em versão resumida, foi primeiramente apresentado na XVIII Jornada do Círculo Psicanalítico de Pernambuco, que debateu o tema: Criatividade e Impasses na Clínica Psicanalítica, nos dias 8, 9 e 10 de dezembro de 2002 no Golden Beach Pathernon Hotel Piedade, em Jaboatão dos Guararapes, Pernambuco. 


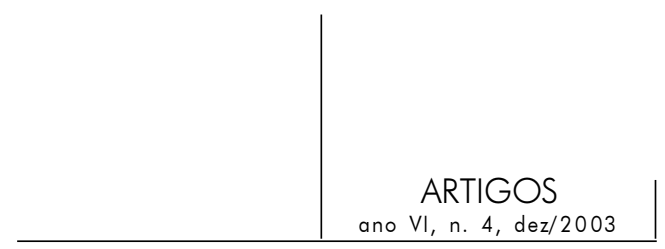

Introdução

O fazer do camponês não desafia o solo do campo.

Ao semear a semente, ele entrega a semeadura às forças do crescimento e protege o seu desenvolvimento.

Heidegger, A questão da técnica

Peço emprestada a Heidegger esta imagem do camponês no ato de lançar suas sementes no seio da terra, confiando nas "forças de crescimento" que as dinamizam e, ao mesmo tempo, assumindo a tarefa de "proteger o seu desenvolvimento". Faço desta imagem, enquanto metáfora do trabalho analítico, o ponto de partida das reflexões que, no presente trabalho, intenciono desenvolver sobre a transferência e a criatividade no tempo da análise.

\section{Transferência e metáfora}

Por que este recurso à metáfora? Primeiramente porque entre ela e a transferência existe uma grande afinidade etimológica. De fato, a palavra grega $\mu \varepsilon \tau \alpha \varphi \circ \rho \alpha$ é composta pela preposição $\mu \varepsilon \tau \alpha$ (que quando rege o genitivo significa "em meio de", "de acordo com", e quando rege o acusativo quer dizer "depois de", ou "a seguir a") e pelo verbo transportar, suportar, carregar). Por sua vez, a palavra transferência, de origem latina, é composta pela preposição trans (que quer dizer "além de") e pelo verbo ferre (que significa "levar" ou "trazer", "transportar" e "suportar"). Portanto, é grande a afinidade etimológica entre as duas palavras.

Mas não é só na etimologia que as palavras "metáfora" e "transferência" têm grandes afinidades; elas também convergem no que diz respeito ao seu poder de criatividade. De fato, a metáfora é mais do que a transferência de significados semelhantes entre conceitos diferentes, e a transferência, no sentido psicanalítico do termo, é muito mais do que a transposição do passado do analisando para a pessoa do analista. Cada uma delas, seja a metáfora seja a transferência, caracteriza-se, de modo singular, pelo espaço que abre para a criação de novos sentidos e de novas significações ou ressignificações. 


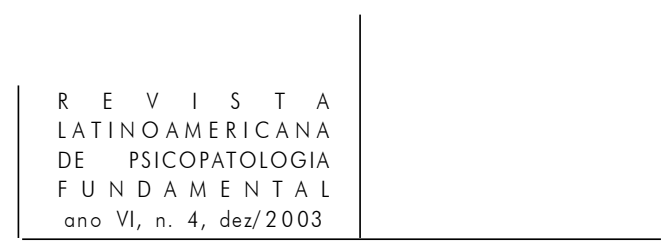

O poder criativo, tanto da metáfora quanto da transferência, manifesta-se, pela mediação da palavra, nos diversos momentos do seu acontecer através da História.

Helena Kon Rosenfeld (1998, p. 111), no belo livro Palavra pescando nãopalavra. A metáfora na interpretação psicanalítica, chama a atenção, com clareza e elegância, para a capacidade que tem a metáfora de despertar diferentes interpretações, evocar pensamentos e emoções e revelar as coisas sob um ângulo novo, descortinando, assim, um novo horizonte de possibilidades. Ora, tudo isso poderia também ser dito da transferência, quando considerada na sua dimensão criativa.

No que se refere ao poder criativo da palavra, Rosenfeld destaca uma analogia muito significativa entre a linguagem da metáfora poética e o que se vive na experiência da análise. De fato, no linguajar cotidiano as palavras são "amarradas" aos seus fins designativos e representativos. Na metáfora poética, elas são livres desses laços. E esta liberdade dá asas à sua criatividade. Ora, foi precisamente para salvaguardar a liberdade do dizer e da fala analítica e, conseqüentemente, proporcionar um espaço adequado ao seu poder criativo, que Freud estabeleceu a "associação livre das idéias" como a regra fundamental do dizer do analisando e a "atenção livremente flutuante", como a regra fundamental da escuta do analista.

82 Retomo, pois, a imagem heideggeriana do camponês no ato de lançar suas sementes no seio da terra e faço dela uma metáfora do trabalho analítico. No trabalho e no espaço da análise, analista e analisando também semeiam as suas palavras e, confiantes, na força de seu crescimento, esperam que elas germinem e frutifiquem. No silêncio da terra, a semente germina e se torna a árvore com a qual o lavrador tanto sonhou. Algo de semelhante acontece com o poder criativo da palavra, quando semeada no espaço e tempo da análise. É o que espero mostrar no decorrer deste trabalho.

\section{Freud e a Transferência}

Freud não descobriu, desde o início de suas pesquisas psicanalíticas, esse poder criativo e renovador da transferência, porquanto foi longo o percurso, por ele seguido, para tomar consciência da importância e do lugar central que ocupa a transferência na situação analítica.

Ainda quando trabalhava com a hipnose, no período catártico de sua colaboração com Breuer, ele pressentiu que havia "algo de misterioso" por detrás da hipnose (Freud, 1925, p. 40). Mesmo sem saber explicar a natureza deste "elemento misterioso", ele logo compreendeu sua importância clínica, porquanto todos os belos resultados do método catártico eram comprometidos, quando o relacionamento do terapeuta com o cliente sofria alguma espécie de perturbação. 


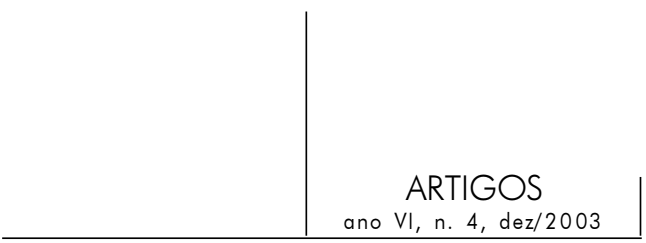

A grande revolução do método terapêutico freudiano aconteceu quando o paciente tornou-se cliente, vale dizer, quando começou a falar em primeira pessoa e em seu próprio nome. Antes, nas técnicas da hipnose e da sugestão, o cliente falava em segunda pessoa, porquanto fazia apenas o que o hipnotizador e o sugestionador lhe ordenavam. Foi quando o seu dizer libertou-se das amarras hipnóticas e sugestivas, que ele se tornou criativo e a situação analítica foi instaurada como um lugar e uma relação de linguagem. Estava, assim, preparado o campo para o acontecimento e a tomada de consciência da transferência.

Isto, porém, só se tornou possível quando o descentramento do sujeito, operado pela introdução da noção de inconsciente, atingiu também a clínica e a figura do analista. Foi só quando o analista se descobriu um "outro", não só do cliente, mas também de si próprio e as artimanhas de seu próprio inconsciente fizeram-no "afetável" pelo dizer do cliente, foi só então que a noção de transferência, com sua ressonância contratransferencial, começou a ter um lugar de destaque na clínica psicanalítica.

Portanto, antes mesmo de receber uma sistematização teórica, ou uma conceituação adequada, e, enquanto tal, ser introduzida na Teoria da Clínica, a transferência já aparece no seu devido lugar. Sua tópica é a do inconsciente e a do inconsciente como um "outro psíquico".

Freud, porém, não viu de imediato o valor positivo nem muito menos renovador da transferência. Ainda, no artigo técnico de 1912 sobre "A dinâmica da transferência", ele deixa transparecer um certo receio em relação à força sedutora das transferências muito intensas, que tinham lugar sobretudo entre as pessoas neuróticas. Para evitar que sobre a psicanálise fossem lançadas as desconfianças que, antes, caíram sobre o método hipnótico, ele se apressa em esclarecer que essas características da transferência muito intensa com forte colorido erótico, deviam ser atribuídas não à psicanálise, mas, sim, à própria neurose (p. 133-43).

Mais ainda: no trabalho da análise, a transferência, sobretudo aquilo que Freud, de modo ambíguo, denominava de "transferência negativa" (die negative Übertragung $)^{1}$ tornar-se-á uma resistência ao tratamento. E não uma resistência

1. Esta denominação de "transferência negativa", que Freud reserva à transferência hostil ou com intensa tonalidade erótica, não parece feliz, pois a chamada transferência negativa pode ter resultados positivos, se for bem elaborada no trabalho da análise. Ao passo que a chamada "transferência positiva", fundamentalmente constituída pela disposição do analisando de querer cooperar com o trabalho de seu analista, pode, em casos especiais, ter resultados negativos, na medida em que podem camuflar os verdadeiros sentimentos do analisando. Não existe, pois, uma transferência positiva ou negativa; existe, sim, a transferência erótica ou hostil com efeitos positivos ou negativos, dependendo da maneira como é elaborada na análise. 


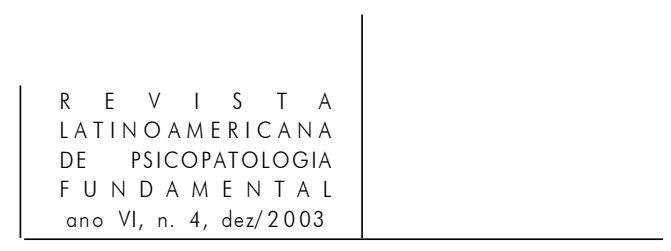

qualquer, mas, para dizê-lo com as próprias palavras de Freud (1912, p. 139): "a arma mais forte da resistência."

Neste estudo sobre a dinâmica da transferência, Freud não ressaltou a força e o dinamismo inerentes ao fenômeno da transferência. E, no entanto, é neste seu dinamismo intrínseco que ela revela a dimensão criativa que lhe é própria, pois a palavra, na transferência, não é só reveladora de sentidos ocultos que se desconhecem, mas é, simultaneamente e sobretudo, portadora de novos sentidos (Laplanche, 1992, p. 417-38).

Para pôr em destaque esta dimensão criativa da transferência, eu vou, primeiramente, situar o tempo da análise no contexto de uma breve síntese da visão filosófica do tempo e relacioná-la com a temporalidade humana que, para os filósofos da existência, e particularmente para Heidegger, é constitutiva da subjetividade. Em seguida, articularei a transferência com o trabalho da interpretação psicanalítica, porquanto somente quando são feitas na transferência, as interpretações tornam-se mutativas e o seu valor adquire uma dimensão verdadeiramente criativa. Comecemos relacionando transferência e tempo.

\section{Transferência e tempo}

Costuma-se criticar a psicanálise freudiana por causa da ênfase, quase exclusiva, que, nela, se dá ao passado. Enquanto alguns filósofos contemporâneos (e eu penso, particularmente, em Martin Heidegger, 1999), relacionando profundamente ser e tempo, definem o ser humano como um zusein, vale dizer, como um ser voltado para o advir e o porvir, empenhado na atualização de suas possibilidades e em um projeto existencial essencialmente voltado para o futuro, a psicanálise veria, no homem, um ser determinado por aquilo que ele foi, visão na qual prevalece o passado.

As vivências de nossos primeiros anos de vida seriam decisivas para determinar e selar o destino de nossa saúde psíquica. O neurótico é um prisioneiro do passado, pois torna-se neurótico precisamente aquele que não encontra um modo saudável de desatar os laços conflitivos que o amarram ao seu passado.

Ninguém poderia negar o peso que as experiências passadas têm no processo de constituição da subjetividade humana. O que somos hoje, inegavelmente, começou a ser construído por aquilo que fomos ontem e o que seremos amanhã dependerá do tamanho da capacidade que temos hoje de sonhar, o que vale dizer, o nosso amanhã depende daquilo que somos capazes de fazer hoje. Mas se é na capacidade atual de sonhar que se esconde o segredo daquilo que seremos amanhã, é bom notar que esta capacidade de sonhar pode ser inibida pelos conflitos não resolvidos de nosso ontem. 


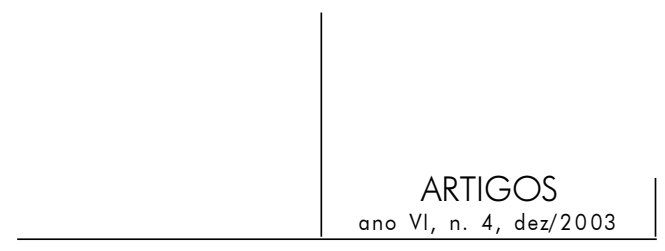

Breve, o que importa não é tanto querer definir qual a parcela do tempo é a mais importante, se o passado, o presente ou o futuro. $O$ mais importante é definir em que visão do tempo se insere nossa maneira de lidar com as três dimensões constitutivas de nossa temporalidade histórica.

\section{Uma visão panorâmica do tempo}

Jean Laplanche, em um denso e interessante estudo intitulado "O tempo e o outro", traça as grandes linhas de quatro visões do tempo que dominaram a História do Pensamento Humano. São elas: o tempo cosmológico (ou o tempo do mundo), o tempo psicológico (aquele que resulta de uma percepção consciente, ou de uma intuição do ritmo das coisas), o tempo existencial (ou a temporalização que é constitutiva da existência humana), e, finalmente, o tempo da história (aquele que distingue os grandes momentos da história da humanidade, ou a de cada uma de nossas histórias individuais). Vou tentar caracterizar, brevemente, cada uma dessas visões do tempo.

O tempo cosmológico remete-nos a uma dupla visão que os antigos pensadores gregos tiveram do tempo, vale dizer, a visão cíclica e a visão mítica. $\mathrm{Na}$ visão cíclica, o tempo é um eterno retorno que não conhece começo nem fim. Essa concepção cíclica e repetitiva do tempo aparece com freqüência no pensamento grego, embora não se possa dizer que ela defina a concepção grega do tempo. Dir-se-ia que, com ela, os antigos pensadores, na linguagem do mito e de inúmeras outras expressões de suas respectivas culturas, tentavam inserir a eternidade no tempo, pois não foram capazes de separá-los.

$\mathrm{Na}$ visão mítica, o tempo, particularmente o tempo religioso, é marcado por uma "estrutura repetitiva", dominada pela lógica do idêntico. Nela, o passado fixa-se na identidade de uma matriz originária, diante da qual o tempo limita-se a fluir sempre igual a si mesmo, na cadência dos anos, dos meses, dos dias e das horas, na sucessão de uma temporalidade que tem o fascínio e o mistério de uma ação sagrada. É o tempo subjacente ao calendário das grandes festas e dos grandes ritos religiosos.

Esta visão do tempo cíclico e mítico prevaleceu nas culturas não-filosóficas, sem no entanto desaparecer de todo mesmo depois da passagem do mythos para o $\log o s$.

Nos poemas homéricos, não se conhecia ainda uma visão abstrata do tempo, nem muito menos uma visão do tempo como duração contínua. O tempo era sentido e vivido, na sua dimensão qualitativa, vale dizer, como algo prazeroso ou desprazeroso. O que mais se ressaltava, então, na vivência do tempo, era seu caráter de transitoriedade. Neste sentido, Hesíodo diz (citado em Lloyod, 


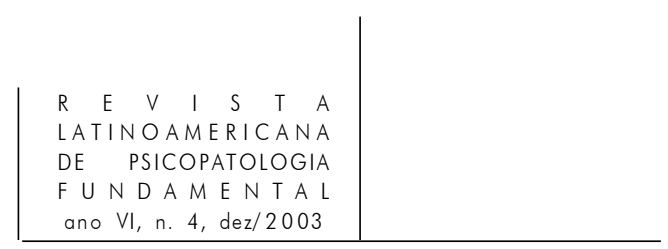

1975, p. 140; cf. Ricoeur, 1975, p. 140), no livro Os trabalhos e os dias, que "um mesmo dia tanto pode ser mãe quanto madrasta". Dito com outras palavras: nesta maneira de ver o tempo, a ordem moral e a ordem temporal estão indissoluvelmente unidas. No tribunal do tempo impera a Diké, pois o tempo "é um aspecto da ordenação moral do universo" (Cf. Lloyod, 1975, p. 24).

Nos poemas líricos e nas tragédias, o tempo é visto de um modo grandioso. Ora ele é "o pai de todas as coisas" ou é "aquele que tudo põe à prova e de tudo revela a verdade", como se exprime Píndaro (apud Lloyod, 1975, p. 1456); ora ele é "aquele que tudo leva a termo", como prefere dizer Ésquilo (apud Lloyod, 1975, p. 145). Às vezes, o tempo consola e faz esquecer as mágoas, o que, no dizer do mesmo Ésquilo, se faz mediante as duras provas de uma sabedoria trágica, que nos ensina a compreender pelo sofrimento $-\pi \alpha \theta \varepsilon \imath \mu \alpha \theta$ os. Outras vezes, ele é considerado a força que tudo destrói, pois esgota a pujança da terra e o vigor do corpo. Só os deuses escapam a essa força destruidora do tempo.

Na Grécia Clássica, Platão e Aristóteles empenham-se em fazer uma elaboração teórica da noção do tempo. Mas ambos ainda concebem o tempo de uma maneira objetiva. Para Platão, o eterno não foi nem será, mas é. E ao que é eterno, opõe-se o que dura através do tempo e da história. No Timeu, o modelo de que se serve o Demiurgo para criar o mundo é eterno, e para tornar a obra semelhante ao modelo, ele procura "uma imagem móvel da eternidade" e a encontra no tempo, que se torna assim "o desdobramento da eternidade no movimento ritmado pelo número" (Platão, Timeo, 37d). Portanto, para Platão, o tempo é um movimento ordenado. Ele surge no momento em que o Demiurgo introduz a ordem na desordem, e transforma o caos no kósmos. O que sempre dura no tempo é o que mais se aproxima da eternidade.

Para Aristóteles, o tempo primeiramente se apresenta como um grande enigma, e é quase impossível dizer qual a sua essência, porquanto suas partes in-existem, pois o passado já existiu, mas não mais existe; o futuro ainda não existe, portanto in-existe e o presente, que é o instante, não pode ser considerado uma parte do tempo, pois este não poderia ser o resultado de um conjunto de instantes. Para resolver o enigma, o Estagirita lança mão das noções do movimento e da alma. O tempo implica o movimento e, na continuidade do movimento, a alma numera-o segundo o antes e o depois. Daí, a definição do Livro IV da Física que se tornou célebre e clássica: "O tempo é o número do movimento segundo o antes e o depois".

Mas para que o movimento seja numerado, é preciso que haja uma unidade de medida que seja numerante, e esta é a alma, pois só a alma tem capacidade de numerar. Não obstante esta articulação com a alma, a visão aristotélica do tempo ainda não é o que se poderia chamar de tempo psicológico. Os estóicos, 


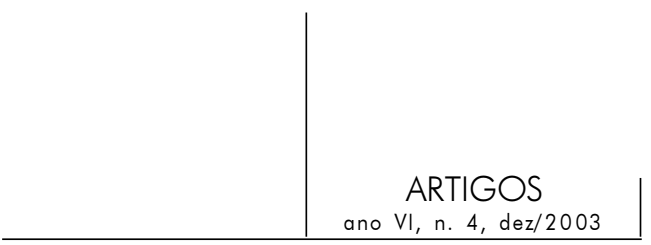

na filosofia helenística, retomaram e divulgaram esta visão do tempo como o ritmo ou a ordem do movimento cósmico. Os grandes precurssores da visão psicológica do tempo foram Plotino e Santo Agostinho.

Plotino rompe com a visão cíclica do tempo. Para tanto, ele procura, na experiência do êxtasis, o momento de uma profundidade infinita, mediante o qual a alma eleva-se por cima dos ciclos repetitivos. Mas Plotino não se livra completamente da visão cíclica, porque sua visão do tempo ainda mistura tempo e eternidade. O tempo começa e se plenifica na eternidade e se desenvolve na ordem temporal. A visão plotiniana do tempo é ainda mítica, mas ela cria um novo tempo mítico, marcado pelas noções de queda e de salvação. A queda e a salvação são dois momentos complementares dos quais um anula o efeito do outro. Mas quem verdadeiramente sistematiza a concepção psicológica do tempo é, sem dúvida, Santo Agostinho.

Isto se deve ao fato de Agostinho ter separado inteiramente tempo e eternidade; depois, por ter unido de modo muito profundo o tempo e a alma humana. Nele mesmo, o tempo não existe, porque o passado é o presente que já não mais existe e o futuro é o presente que ainda não existe. O presente, se existisse sempre como presente, não seria o tempo, mas a eternidade. $\mathrm{O}$ passado só existe porque a alma o rememora, o futuro também só existe enquanto a alma o espera e o presente só existe porque a alma o intui. Portanto, o que existe é o presente do presente (praesens de praesentibus), o presente do passado (praesens de praeteritis) e o presente do futuro (praesens de futuris). Assim, o passado e o futuro encontram-se no interior do presente que é a minha consciência e percepção do tempo (Agostinho, Confissões, XI, 28). Assim considerado, o tempo é uma distentio animi que se manifesta como memória, intuição e espera.

$\mathrm{Na}$ filosofia moderna, esta visão psicológica do tempo foi retomada em um nível de reflexão mais profunda por Bergson, que definiu o tempo como "duração" (durée) e por Edmund Husserl, quando concebeu o "tempo fenomenológico" como uma "corrente de vivências", na qual tudo se conserva em uma espécie de eterno presente. Na concepção bergsoniana do tempo como duração, duas coisas devem ser ressaltadas: a novidade absoluta de cada instante no processo contínuo de criação e a conservação integral de todo passado. $\mathrm{O}$ que, em última análise, faz do tempo um eterno presente, na medida em que é presente do presente, presente do passado e presente do futuro.

De fato, nesta maneira psicológica de abordar o estudo do tempo, é o presente que termina prevalecendo entre as demais parcelas em que se divide o eterno fluir do tempo. Este, como ordem do movimento, é uma totalidade presente, pois, como explica Abbagnano (1998), "toda ordem pressupõe a simultaneidade de suas partes, de cuja recíproca adaptação ela nasce". 


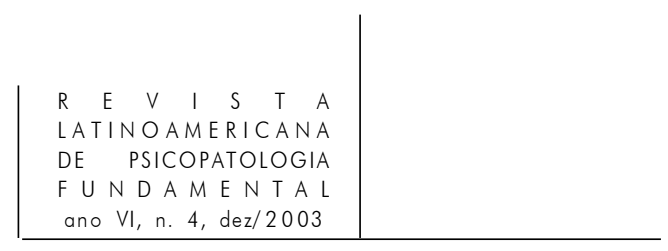

Kant vê no tempo a condição de todo conhecimento possível. Para ele, só pode ser conhecido o que é informado pelo espaço e pelo tempo, que são as formas a priori da sensibilidade. De fato, só pode ser conhecido o que se manifesta no tempo e no espaço. Aquilo que não se manifesta, a coisa em si é incognoscível. Portanto, tudo o que conhecemos dentro e fora de nós, nossas percepções tanto internas quanto externas, tudo o que o homem percebe a respeito de si e fora de si, só o pode fazer no tempo. Nisto se fundamenta, para Kant, a historicidade do ser humano. Na analítica transcendental, as categorias são aplicadas aos fenômenos pela mediação dos esquemas transcendentais, que se estruturam no tempo.

Depois de Kant, o tempo passou a ser visto como temporalidade, ou seja, como o tempo do sujeito, elemento constitutivo da subjetividade humana, pois através do processo de temporalização, que articula presente, passado e futuro, o homem constrói seu próprio tempo.

\section{Freud e o tempo}

Traçada esta visão panorâmica do tempo, vejamos de que modo Freud, nela, se situa. Segundo Laplanche, o tempo é abordado nos textos freudianos de duas maneiras distintas: temos, primeiramente, uma teoria explícita elaborada nos moldes da teoria psicológica da percepção, que lida prevalentemente com a noção ou com a idéia do tempo. Depois existe uma teoria implícita, mais condizente com aquilo que é específico da concepção psicanalítica do homem e esta teoria implícita poderia ser articulada com a noção de tempo vivido ou, melhor ainda, com a concepção existencial do tempo humano.

Freud refere-se a essa teoria explícita do tempo em uma passagem de "Além do princípio do prazer" (1920), na qual, depois de se referir claramente à concepção kantiana do tempo (enquanto condição de possibilidade do conhecimento), afirma que o inconsciente é zeitlos, vale dizer, é atemporal, pois os seus processos não são ordenados nem alterados pelo tempo. O que não deixa de ser surpreendente e estranho, porquanto a própria noção de "processo" já parece implicar, de alguma forma, uma certa temporalidade.

Por isso, o próprio Freud apressa-se em esclarecer que esta característica do inconsciente, ou seja, a sua Zeitlosigkeit ("atemporalidade") impõe-se na medida em que o conceito do tempo é relacionado à consciência. Para dizê-lo com as palavras do próprio Freud:

Nossa representação abstrata do tempo parece ser completamente sustentada pelo modo de trabalhar do sistema percepção-consciência (Unsere abstrakte Zeitvorstellung scheint vielmeher durchaus von der Arbeitsweise des 


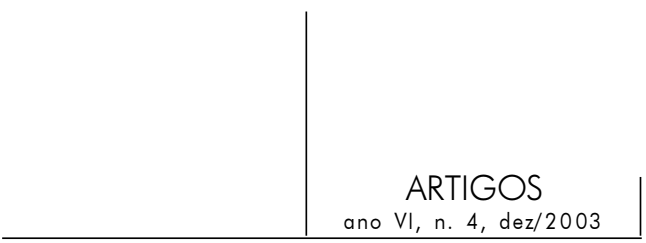

Systems W-Bw hergeholt zu sein) e corresponder a uma autopercepção do mesmo (und einer Selbstwahrnehmmung derselben zu entsprechen).(1920, p. 43-4)

No artigo de 1925 - "Uma nota sobre o Bloco Mágico" -, Freud volta a se posicionar diante da problemática do tempo. Unindo percepção e consciência em um só sistema, o sistema percepção-consciência (Pcpt-Cs), ele lembra que, neste sistema, os investimentos não são contínuos. Para que o sistema esteja sempre aberto para poder receber novas percepções, é preciso admitir uma certa periodicidade e descontinuidade nos investimentos. Freud então conclui: "A maneira descontínua de trabalhar do sistema Pcpt-Cs fundamenta a origem da representação do tempo (diese diskontinuierliche Arbeitsweise des Systems $W-B w$ der Entstehung der Zeitvorstellung zugrund liege) (p. 290).

Portanto, na teoria explícita, Freud relaciona o tempo à percepção consciente do mundo exterior e faz do ritmo periódico de seus investimentos, o seu fundamento. Temos, assim, uma concepção não contínua, mas periódica e descontínua do tempo, em que o ritmo é fundamental, de tal modo que, como observa Laplanche (1992a, p. 232), o ritmo poderia ser visto como o próprio tempo do tempo.

Esta teoria explícita trata do tempo perceptivo imediato, o qual tem seu eixo fundamental no presente. Para Jean Laplanche, ela não é adequada ao que é específico da visão psicanalítica do tempo e da história. Ela seria um dos múltiplos avatares da tentativa de se querer construir uma psicologia a partir de noções psicanalíticas. Estas, então, terminam perdendo sua especificidade e seu caráter de estranheza.

Todavia, facilmente se entende que não é a visão perceptiva do tempo objetivo aquela que melhor define a "temporalidade psicanalítica". De fato, o que está em questão no estudo freudiano do tempo, é avaliar de que modo o psiquismo humano pode criar significações novas e novos sentidos para estruturar sua realidade histórica, pois é mediante essas significações que o homem se constitui como sujeito. ${ }^{2}$ Isso já se anuncia desde a Carta 52 enviada a Fliess, na qual Freud (1950[1892, 1899, p. 317) apresenta o psiquismo como um conjunto de sistemas que se constroem e se reconstroem a partir do modo como os traços mnésicos, principalmente aqueles libidinalmente investidos, associam-se entre si.

Por isso, nos meios psicanalíticos acredita-se, hoje, que a doutrina heideggeriana sobre a temporalidade, apresentada na Analítica Existencial do Sein und Zeit, oferece-nos valiosos subsídios para uma melhor compreensão desse

2. Veja-se a este respeito o que escreve Monah Winograd no capítulo segundo de seu livro Genealogia do sujeito freudiano, p. 41-54. 


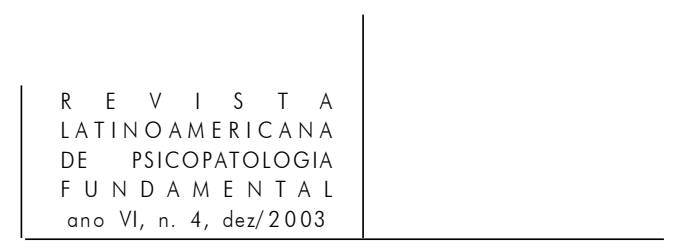

tempo que é próprio do homem e que, por conseguinte, tem um papel decisivo no trabalho de reestruturação da subjetividade, que se faz no espaço da análise.

\section{Heidegger e a temporalidade ${ }^{3}$}

Embora não seja fácil, vou tentar resumir o que me aprece essencial naquilo que Heidegger escreve sobre a temporalidade. Enquanto possibilidade da possibilidade, a temporalidade torna possível a existência do ser-no-mundo como poder-ser e revela a dimensão temporal do Dasein que existe na medida em que se temporaliza entre nascimento e morte (Nunes, 2002, p. 31). Além do mais, a temporalidade modifica a concepção tradicional e comum do tempo. De fato, tanto a concepção popular quanto a concepção filosófica vêem o tempo como uma sucessão de agoras. O tempo numera esta sucessão segundo a ordem do antes e de depois. Passado é tudo o que veio antes do agora que define o presente, e futuro é tudo o que virá depois.

Heidegger modifica este modo de conceber o tempo. Para ele, o tempo não é uma sucessão linear de agoras, pois passado, presente e futuro são momentos (ou êxtases, como diz ele), nos quais a temporalidade se temporaliza e estão íntima e mutuamente interligados e imbricados. O passado não acaba nunca de passar, por isso ao invés de designá-lo com a palavra Vergangenheit, normalmente utilizada, em alemão, para denominar o tempo passado, Heidegger prefere o termo Gewesenheit, que a tradutora do Sein und Zeit verteu com a expressão: Vigor de ter sido, que se pode entender como "uma força que se instalou e que continua atuante". ${ }^{4}$ Portanto, como um passado-presente. Ou, para dizê-lo com as palavras de Heidegger (1990, p. 120): "A pré-sença (Dasein) só pode ser o vigor de ter sido (Gewesenheit) na medida em que é e está por-vir." A Gewesenheit é um passado que se repete e se renova em uma Wiederholung, vale dizer, em uma repetição que é uma retomada do que foi e continua sendo possível. Os franceses diriam uma "reprise".

3. O resumo que vou apresentar sobre a concepção heideggeriana da temporalidade, muito deve ao pequeno grande livro que Benedito Nunes escreveu sobre Heidegger \& ser e tempo (2002).

4. Ver na tradução brasileira do Sein und Zeit, a nota explicativa em que a tradutora explica o sentido da palavra Gewesenheit. Veja-se Ser e tempo, Parte II, p. 260.

5. A este propósito é oportuno lembrar que Kierkegaard, em um texto de 1843, já se refere ao conceito de "repetição" (reprise na tradução francesa) como a uma autêntica forma de recriação. Agradeço a Luís Cláudio Figueiredo ter chamado minha atenção para a importância e o alcance deste conceito kierkegaardiano de repetição. 


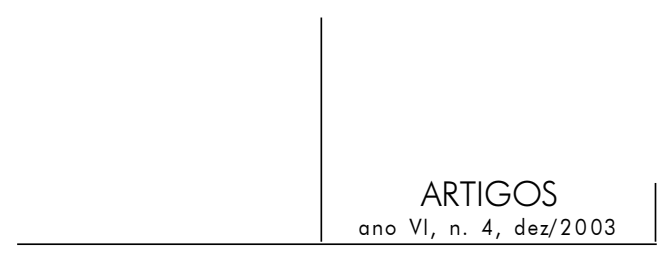

É muito expressiva a etimologia da palavra Wiederholung. Busca-se (holen), novamente (wieder) e, de um modo renovado, aquilo que já se obteve. Trata-se, pois, de uma repetição que não é uma mera e simples repetição, mas uma repetição que recupera, renova e restaura o que se repete. Trata-se de uma repetição, mas não da repetição do mesmo, mas da repetição do diferente, vale dizer, do mesmo com novos sentidos e ressignificações.

Se é assim que Heidegger olha o passado, o presente, para ele, não se restringe a um simples agora. Na dinâmica da temporalização, o presente é um Gegenwart, vale dizer, uma atualização de possibilidades, em que se misturam forças ativas que resistem (gegen) - pois ao que é novo quase sempre se resiste - e que projetam o que se espera (warten). Quando se espera, olha-se para o que ainda virá. Assim sendo, o presente, no seu está sendo, articula o porvir (futuro) ao vigor do ter sido (passado) e se torna "o instante da decisão", em que o Dasein assume o projeto existencial que define o seu ser no mundo.

Portanto, na concepção heideggeriana, a temporalidade humana, enquanto possibilidade do poder-ser, está sempre dirigindo o ser humano, enquanto situado no mundo, para o "porvir" (Zukunft), abrindo-o, dessa maneira, para um horizonte de possibilidades infindas. É preciso não esquecer que, para Heidegger (1990), o porvir (Zukunft) não se limita a designar um acontecimento que aindanão aconteceu, e que depois acontecerá. "Porvir", esclarece Heidegger, "significa o advento em que a pré-sença (Dasein) vem a si em seu poder-ser mais próprio" (p. 119).

Não há situação, por mais difícil e dolorosa que seja, que possa esgotar as possibilidades do poder-ser. Nenhuma das possibilidades concretas que a vida oferece é definitiva. Nenhuma situação é tal, a ponto de se dever concluir diante dela: "agora nada mais é possível". Enquanto existir a temporalidade, existirá sempre a possibilidade de mudança e de transformação. Nenhuma das possibilidades do Dasein o realiza como um todo ou uma totalidade.

No horizonte dessas possibilidades, encontra-se, também, a "possibilidade da impossibilidade" que, para Heidegger, é a morte. "Ela é a possibilidade da pura e simples impossibilidade do Dasein, aquela que o atinge no seu estar-aí, na essência mesma do seu ser de projeto. Somente a morte põe termo e totaliza o continuo fluir das possibilidades que definem o Dasein. Mas é só quando assume esta possibilidade da impossibilidade que a existência torna-se autêntica. Compreende-se que, para Heidegger, seja o futuro que tem a primazia entre os momentos que constituem a temporalidade humana. "O projetar-se - escreve ele - em função de si mesmo, fundado no porvir, é um caráter essencial da existencialidade. O seu sentido primordial é o porvir" (ibid. p. 122; grifos do autor). 


\section{O tempo da análise}

Evidentemente não teria sentido querer inserir o tempo da análise, ou da experiência analítica, nos moldes da analítica existencial heideggeriana. Mas daí não se segue que o essencial daquilo que Heidegger escreve sobre o passado, enquanto modalidade do tempo que não passa de passar e se repete de um modo renovado no presente, e sobre o presente, enquanto instante da decisão, em que convergem o por vir e o vigor do ter sido, não há como negar, repito, que tudo isso ajuda, e muito, a melhor compreender aquela teoria implícita do tempo que existe nos textos freudianos. Nela, Freud oferece elementos inestimáveis, mesmo sem teorizá-los, para uma visão do tempo, na qual se destaca a temporalidade histórica constitutiva da subjetividade humana.

À primeira vista, a visão heideggeriana da temporalidade parece diametralmente oposta à visão psicanalítica do tempo. Enquanto Heidegger ressalta a primazia do porvir, Freud destaca o papel da regressão e da fixação na sua teoria das neuroses. Além disso, a história do desenvolvimento libidinal e o próprio processo de constituição da subjetividade são marcados pelas alternâncias progressivas e regressivas de nossa temporalidade humana. Sabe-se que, para Freud, o trabalho de análise, enquanto análise, procura, no passado, as causas dos distúrbios psíquicos. Sabe-se também que, contra Jung, Freud não sentia necessidade de incentivar grandes sínteses e sempre aconselhou aos analistas que se abstivessem de traçar planos ou construir ideais para seus analisandos.

Mas com isto, ele de modo algum estava querendo dizer que, na análise, não se pode construir um novo projeto de vida, ou não se pode dar à própria vida uma nova estilística de existência. O que Freud defende é que um tal projeto deve ser do cliente e não do analista. Não é freudiana a idéia que circula com freqüência nos meios psicanalíticos, assegurando que a verdade de todos os nossos projetos está naquilo que foi vivido no passado. Por mais que tenha valorizado o passado, não me parece que Freud tenha feito dele a verdade daquilo que somos ou que projetamos construir na vida.

\section{Trabalho do luto}

A este propósito, parece-me muito pertinente a comparação que faz Laplanche entre o trabalho da análise e o trabalho de luto (1992, p. 374-9). No trabalho de luto, existe necessariamente uma volta ao passado, mas ela será mortífera se enclausurar o sujeito no vazio de sua perda ou nas recordações do seu passado. No trabalho do luto, analisam-se todos os mínimos detalhes, por meio dos quais a libido foi investida no objeto, cuja ausência é pranteada no luto. 


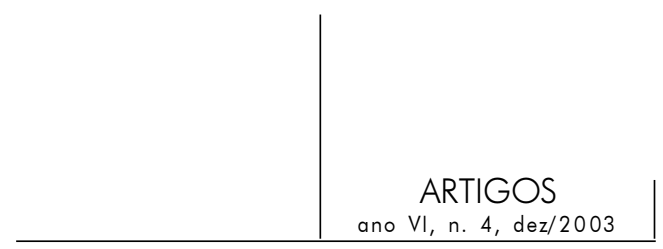

$\mathrm{Na}$ vida, estamos continuamente criando laços e dando nós em tudo o que amamos. No trabalho do luto, procura-se desfazer esses laços e desatar esses nós, tantas vezes quantas forem necessárias. No dizer de Freud, o trabalho do luto é uma verdadeira Lösung e uma Ablösung, vale dizer, um verdadeiro trabalho de "solução" e de "substituição", que por causa de suas ressonâncias inconscientes, faz do luto um verdadeiro enigma.

No seu belo texto sobre a Vergänglichkeit, ou seja, sobre a Transitoriedade, Freud (1927, p. 345) chama a atenção para esta dimensão enigmática do luto. Por mais que se procure compreendê-la, ela está sempre fazendo aparecer novas obscuridades. E o mais difícil é explicar por que razão é tão doloroso, no trabalho do luto, esta tarefa da Ablösung (substituição) do investimento libidinal. Dir-seia que o ego reluta em querer desinvestir o que primeiramente foi investido e, mais ainda, em querer substituí-lo por um outro objeto de amor. Sabe-se que, para Freud, existe uma "viscosidade" da libido que dificulta todo trabalho de desinvestimento. Não se desinveste facilmente aquilo que antes foi investido. Melhor ainda: talvez o trabalho de reinvestimento somente seja possível depois que todos os nós e todos os laços, que foram dados em nossas relações afetivas, tiverem sido desfeitos. Não se trata de destruir os investimentos objetais, mas de "desamarrar" e "desatar" os laços, sem destruir seus fios, para poder refazêlos, de outra maneira, ou reempregá-los em novos investimentos.

A esse respeito, Laplanche sugere que se veja em Penélope, a fiel esposa de Ulisses, um exemplo paradigmático do trabalho de luto. Quando todos acreditavam que seu marido não mais retornaria da longa viagem e os pretendentes já começavam a cortejá-la para ocupar o lugar vazio deixado pelo esposo desaparecido, ela sentiu necessidade de fazer primeiramente o luto dessa dolorosa perda, e se deu, como tarefa, o trabalho de fiar um longo tecido. Antes que o trabalho fosse terminado, ela não se disporia a aceitar nenhuma proposta de casamento. Mas o que ela fiava e tecia de dia, desfiava e destecia de noite, e, desse modo, dava-se o tempo de que precisava para fazer seu trabalho de luto.

Desfazer os laços tantas vezes quantas forem necessárias, para que, depois, novos laços possam ser refeitos, tal é o sentido do trabalho de luto. E aqui a palavra "sentido" deve ser entendida tanto na acepção de "significação", quanto na de "rumo". Se o trabalho precisa ser feito e refeito tantas vezes, é por causa das implicações inconscientes que acompanham os investimentos libidinais. Somente depois desse trabalho de resolução e de desprendimento, a libido tornase disponível para outros investimentos, que assegurarão um novo amanhã e novas perspectivas de vida para aqueles que, hoje, estão empenhados em fazer o trabalho de luto. Portanto, no trabalho de luto, presente, passado e futuro estão intimamente inter-relacionados. Nada ilustra melhor essa inter-relação, do que a 


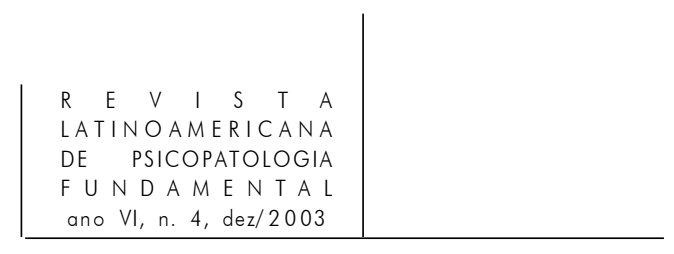

noção freudiana de Nachträglickeit. Nela, provavelmente se encontra o segredo daquilo que define a especificidade da concepção psicanalítica do tempo.

\section{A noção de Nachträglichkeit}

O termo não tem tradução fácil. A palavra alemã Nachträglichkeit é composta pela preposição nach (que significa "depois"), pelo adjetivo verbal träglich, oriundo do verbo tragen (que normalmente significa levar, carregar) e pela terminação keit usada na formação dos substantivos femininos. A palavra Nachträglichkeit, assim composta, pode ser correta e elegantemente traduzida pela expressão "só depois". Na forma adjetiva, ela se traduz pelo adjetivo "posterior" e, na forma adverbial, pelo advérbio "posteriormente". Como quer que seja traduzido, o termo Nachträglichkeit, graças a Lacan e ao Vocabulário de Laplanche e Pontalis, terminou adquirindo o estatuto de um conceito fundamental da metapsicologia freudiana, e, enquanto tal, tornou-se o cerne da concepção psicanalítica do tempo. Senão vejamos.

Freud elaborou o conceito de Nachträglichkeit para explicar como uma experiência vivida no passado, para a qual nenhuma significação pôde ser encontrada, pode, muito tempo depois, encontrar seu sentido e eficácia pelo remanejamento de seus traços mnésicos. Portanto, o que permanece durante tanto tempo apenas como um apelo de sentido, "só depois" (nahcträglich) encontra a sua verdadeira significação. Como isto acontece?

Muitos psicanalistas, influenciados pela tradução inglesa - deffered action - interpretam a Nachträglichkeit, no contexto de uma concepção linear do tempo, como um acontecimento que, vivido hoje, só vai adquirir sua eficácia depois. Tratar-se-ia, pois, de um acontecimento com seu "efeito retardado". Todavia, no momento em que Freud adverte que não é o acontecimento em si, mas a sua lembrança que "só depois" (nahcträglich) torna-se patogênica ou adquire a sua eficácia psíquica, ele parece chamar a atenção para o fato de que é na ordem simbólica dos traços mnésicos e das representações e não no registro da realidade objetiva dos acontecimentos externos, que se dá o remanejamento temporal da Nachträglichkeit.

Aquilo que a define, portanto, é a capacidade que tem o psiquismo de reconstruir o passado no presente, remanejando suas representações e integrandoas naquilo que define o projeto existencial de cada um. Ao determinismo psíquico que, inicialmente, fascinou o próprio Freud, mediante o qual o nosso presente e futuro seriam determinados pelo passado, a Nachträglichkeit abre espaço para uma experiência especial do tempo, na qual é no presente que o passado é ressignificado, pois ele não acaba de passar e suas possibilidades podem sempre ser atualizadas no presente e integradas no projeto que aponta na direção do futuro. 


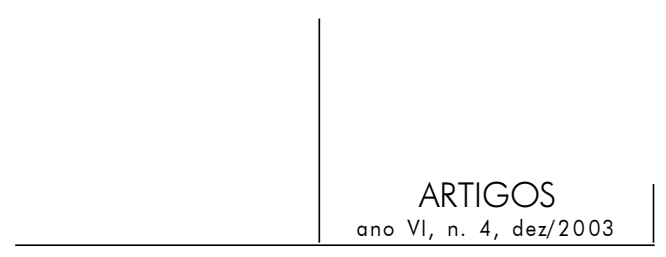

Assim, mediante a Nachträglichkeit, o sujeito torna-se capaz de ressignificar acontecimentos passados, na medida em que lhes pode dar novas significações, particularmente quando esses acontecimentos, por múltiplas razões, não puderam, no momento em que foram vividos, ser integrados em um contexto simbólico e significativo. O tempo adquire assim uma dimensão nova que os antigos desconheceram. Ele perde aquela aura que tinha a força cega de um destino e que fazia o poeta Antônio Machado dizer: ayer es nunca más, ou seja, “ontem é nunca mais". O ontem pode ser retomado e ressignificado hoje, e, como tal, orientado e reorientado para "o amanhã que é sempre". Só isto já é suficiente para demonstrar a importância que a Nachträglichkeit tem na clínica psicanalítica.

Neste contexto, Luís Cláudio Figueiredo, no artigo "Temporalidade e narratividade nos processos de subjetivação da clínica psicanalítica" (1998, p. 271-82) ${ }^{6}$, lembra como em determinados casos clínicos muito difíceis - "feridas abertas por traumas devastadores que destroem até os recursos mais regenerativos do psiquismo" -, casos esses que são acontecimentos que ele designa como "inconclusos e irrecuperáveis pela memória" (pois aconteceram em um momento, em que o sujeito ainda não era capaz de poder experimentálos), mesmo em semelhantes casos, pode-se nachträglich, isto é, posteriormente, no espaço e no tempo da análise, criar as condições para que eles terminem de acontecer e sejam vividos e significados. Em tais casos, a Nachträglichkeit possibilitaria não apenas a reconstituição de um novo sentido, mas "que tais acontecimentos acabassem de acontecer, que simplesmente acontecessem e pudessem ser experienciados e significados".

Nessas reflexões que acabo de fazer, espero ter colocado em destaque alguns aspectos essenciais da temporalidade psicanalítica e da temporalidade humana, à luz dos quais facilmente se verá a dimensão criativa da transferência no tempo da análise. Neste tempo, o passado que se repete, significa-se, ou (re)significa-se, abrindo perspectivas de futuro e novos sentidos para a vida humana. Vou, agora, procurar mostrar o dinamismo intrínseco e criativo da transferência, articulando-a com a interpretação psicanalítica.

\section{Transferência e interpretação psicanalítica}

Na transferência, acontecimentos passados são revividos e encontram uma nova significação, sendo, desse modo, integrados ao contexto simbólico que

6. Palestra pronunciada no XXVI Congresso Interamericano de Psicologia - julho de 1997. Este texto foi publicado em espanhol com o título "Temporalidad y narratividad en los processos de subjectivación de la clínica psicoanalitica”. 


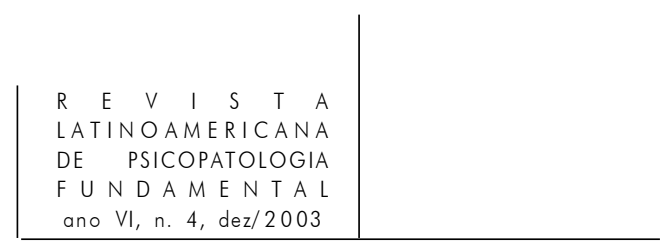

sustenta nossas relações intersubjetivas. Vou mostrar, agora, que esta ressignificação é feita pela palavra ou, melhor ainda, pela força renovadora da palavra, na medida em que é através dela que se faz o trabalho de interpretação na análise.

No trabalho analítico, o objetivo da interpretação não se reduz a descobrir o sentido oculto das formações do inconsciente, como se se tratasse de um sentido já configurado, mas escondido, à espera da interpretação do analista. De fato, na perspectiva psicanalítica, interpretar é mais do que revelar o sentido desconhecido que se esconde nas lacunas do que é dito no espaço da análise. Revelar o sentido oculto é o trabalho dos hermeneutas quando se debruçam sobre os livros sagrados para descobrir o sentido literal ou figurado dos seus textos.

Nietzsche dizia que nossas experiências mais profundas são mudas, porquanto a linguagem instrumental de que nos servimos, como meio de comunicação, não é capaz de fazê-las falar. Para dar nome ao que é mais profundo dentro de nós, é preciso utilizar uma outra forma de linguagem, que, além de sua função designativa, tenha também uma função verdadeiramente criativa. E, para ele, o modelo de semelhante linguagem criativa é a linguagem da arte.

Creio que se poderia também dizer que a interpretação psicanalítica utiliza uma linguagem desta natureza, pois quando procura dar nome às nossas representações, que por causa do recalque tornaram-se mudas, ou, pior ainda, como acontece nos casos mais graves, foram jogados fora do universo da simbolização, ou ainda quando procura dar nome aos nossos afetos inibidos ou deslocados, ela emprega uma fala, que a linguagem comum não consegue exprimir.

O grande problema que então se põe, é procurar dizer o não-dito, é libertar, pela palavra, o afeto, sem correr o risco de sufocá-lo. O poeta faz também a experiência desta angústia, quando recorre às palavras para "fazer existir o inexistente" ", ou para dizer o indizível. A este propósito, Octávio Paz (1990, p. 117) escreve: "A expressão poética é irredutível à palavra, mas só a palavra a expressa", e, na mesma linha de reflexão, Rosenfeld (1998, p. 117) afirma: "A interpretação analítica toca o indizível, mas este indizível não tem outra forma de expressão, senão pela palavra”. Como proceder, portanto, para que na interpretação psicanalítica a palavra consiga libertar sua força criativa?

Como subsídio filosófico para uma melhor compreensão desta dimensão criativa da palavra, vou lembrar, rapidamente, o que Heidegger nos ensina sobre as origens do dizer e do falar. Ele mergulhou nessas origens de um modo que

7. "Vives, apenas, para o que já vive / mas fazer existir o inexistente / é toda a glória de se ser poeta". Daniel Lima. "Soneto do vôo do cavalo". In: Ideário humanístico (texto datilografado cujo acesso me foi concedido pelo autor). 


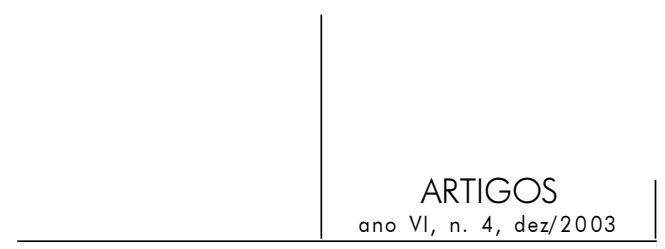

só ele sabe fazer, quando se deu a tarefa de comentar o Fragmento 50 de Heráclito de Éfeso, o qual, inegavelmente, pode e deve ser considerado o primeiro grande filósofo do Lógos. De novo, confrontar-nos-emos com algumas reflexões filosóficas, que, sem pretenderem substituir a teoria psicanalítica, podem nos ajudar a ver o que se esconde nas fontes do dizer e do escutar, cuja importância é fundamental quando se trata da interpretação no tempo e no espaço da análise.

\section{Nas origens do lógos}

Para descobrir o sentido originário do lógos, Heidegger reflete sobre a etimologia do verbo légein. Na língua grega, o verbo légein significa "dizer" e "falar". Mas em seu sentido mais arcaico esse mesmo verbo também significa "pousar" e "recolher". Pois bem, quando faz a passagem do sentido mais arcaico do légein-recolher para o légein-dizer, Heidegger descobre o sentido originário do lógos. Esta passagem operou-se por meio de um processo de desvelamento feito pela linguagem. É quando nomeia o que foi primeiramente recolhido, ou quando revela, ou desvela, o que foi antes velado, que se manifesta o sentido originário do dizer.

De fato, o légein-recolher é também um velar e ocultar. Talvez tenha sido isso que Heráclito quis dizer, quando, no Fragmento 50, afirmou que "para aquele que ouve o lógos, é sábio consentir em dizer que Tudo é Um” (1959, p. 220). O lógos recolhe, na unidade do Um, todas as coisas. O légein-dizer revela e desvela o que foi recolhido e velado pelo lógos na unidade do UM. Ou, para dizê-lo com as palavras do próprio Heidegger, "esta desocultação do oculto, no desvelado, é a presença daquilo que se presenta" (Heidegger, 1973, p. 117-29). E, enquanto se presenta, ilumina-se, acontece.

Mas há sempre um permanecer velado na proximidade daquilo que se "presenta" e se ilumina. E é neste jogo do velar-se e do desvelar-se, que está, para Heidegger, o segredo do ser dos entes, da essência da verdade e da linguagem. Não sendo este o lugar oportuno para refletir sobre a Questão do Ser e a Questão da Verdade, vamos recordar, brevemente, sobre o que ele diz sobre a essência do dizer e do escutar.

\section{Dizer e escutar}

No jogo do velar-se e desvelar-se, Heidegger encontra a essência do dizer. Esta, porém, não se esgota na expressão verbal. A essência do dizer é o desvelamento daquilo que o Lógos primeiramente recolheu e ocultou e, agora, desvela, na medida em que as coisas se "presentam" na presença. A essência do 


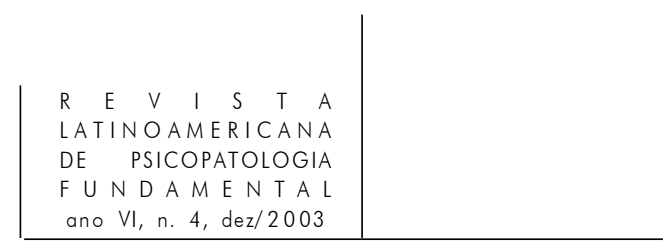

dizer está neste automostrar-se dos entes na "clareira", como manifestações do Ser. Manifestação esta que se faz pela linguagem.

Mas todo dizer supõe um escutar. E escutar, por sua vez, é mais do que simplesmente captar os sons das palavras que se ouve. Escutar exige uma atitude de recolhimento e de concentração na palavra que nos é dirigida. Escuta-se, diz Heidegger, quando se é "todo ouvidos". Para escutar verdadeiramente, é preciso estar em sintonia com a palavra que nos é dirigida. E Heidegger acrescenta: Só se escuta quando o légein-dizer desdobra-se em um o $\mu \mathrm{o} \lambda \mathrm{o} \gamma \varepsilon \mathrm{v}$, vale dizer, quando homologamos o dizer que nos é dirigido. Dir-se-ia que, para escutar, é preciso criar primeiro uma disposição interior de acolhimento para a palavra que nos é dirigida. Somente assim ela - como faz a semente quando é acolhida no coração da terra - germina e desvela os inúmeros sentidos que, nela, foram primeiramente recolhidos pelo lógos.

Estas reflexões ajudam-nos a repensar o dizer e o escutar no espaço e no tempo da análise. Se verdadeiramente só se escuta, quando se cria um espaço de acolhimento interior para receber a palavra que nos é dirigida, então compreende-se melhor a importância decisiva daquela atitude do analista, que Luís Cláudio Figueiredo (2002) $)^{8}$ designou como "contratransferência primordial", vendo, nela, "a condição de possibilidade do psicanalisar".

Esta atitude, que essencialmente consiste em "deixar-se afetar e interpelar pelo sofrimento alheio", está na origem das relações transferenciais. Ela, no entanto, esclarece Luís Cláudio Figueiredo, não se restringe ao campo da análise, mas está na origem do vir a ser do sujeito, pois "é um dos aspectos de nossa condição humana de desamparo, o que tanto acarreta uma vulnerabilidade extrema a toda sorte de abusos e traumatismos, como, em contrapartida, é a base da constituição do psiquismo" (ibid.).

É nesta "contratransferência primordial" que se esconde o segredo de nossa capacidade de escuta. Trabalhando e retrabalhando esta contratransferência, criase o espaço interior de acolhimento para o encontro com a palavra do outro na sua alteridade. E somente assim a palavra do outro pode ressoar dentro de nós e atualizar suas possibilidades de significação e sentido.

Seguramente foi para garantir esta capacidade de escuta que Freud, nos seus escritos técnicos, tanto insistiu, seja na "atenção livremente flutuante" como regra fundamental da escuta analítica, seja naquela aparentemente paradoxal atitude

8. Texto inédito (cujo acesso me foi possibilitado pelo autor) baseado nas reflexões apresentadas na palestra de encerramento da Jornada da Formação Freudiana (Rio de Janeiro, julho de 2002), no VI Congresso de Psicopatologia Fundamental (Recife, setembro de 2002) e na Jornada do Círculo Psicanalítico de Minas Gerais (Belo Horizonte, setembro de 2002). 


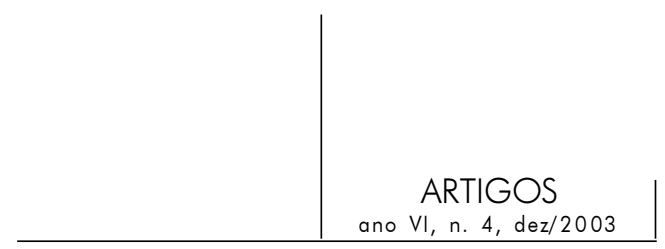

de "neutralidade benevolente", indispensável para que se forme o espaço da transferência.

A atenção livremente flutuante é uma atitude metodológica que possibilita uma escuta despojada de "pré-conceitos", os quais poderiam inibir a criatividade do dizer e a possibilidade de uma autêntica escuta. A "neutralidade benevolente" assegura, por sua vez, uma escuta que não se restringe à dimensão do ouvir, mas abre espaço para um recolher, acolher e sintonizar interiormente com o dizer do outro.

Talvez parafraseando Antoine de Saint Exupéry (1953, p. 474) que escreveu: "Só se conhece bem com o coração", pudéssemos dizer: Só se ouve bem com o coração. O essencial é invisível aos olhos e aos ouvidos. É que nossa capacidade de acolhimento interior e de sintonização espiritual depende de nossa capacidade de amar. Provavelmente foi isso que Heráclito de Éfeso quis dizer quando, no Fragmento 50, afirmou que só ouve o lógos, aquele que "homologa" o seu dizer.

\section{À guisa de uma conclusão}

E termino com a metáfora do semeador, com a qual comecei. O semeador semeia as suas sementes no coração da terra, confia nas forças de seu crescimento e protege o seu desenvolvimento. A metáfora da semente revelanos, de um modo que só a metáfora pode fazer, o trabalho da transferência no tempo da análise. Como a metáfora, a transferência tem, ela também, uma força criativa. Ressignificando o passado, ela o recupera, abrindo-o para inúmeras outras possibilidades e significações. A palavra, na sua força criadora, desvela e revela aquilo que o dizer originário primeiramente recolheu e ocultou. Mas para que o oculto se desvele no dizer, é preciso que a ele consinta um escutar, pois sem este acolhimento da escuta, as palavras semeadas não caem em terra boa e não germinam. E se as sementes não germinam, elas ficam sozinhas no coração da terra, sem poder jamais ver a luz do dia e perder-se-ão, para sempre, na noite do não-acontecido.

\section{Referências}

Abbagnano, N. Dicionário de filosofia. Tradução de Alfredo Bosi. São Paulo: Martins Fontes, 1998.

Aristóteles. The Basic Works of Aristotle. Ed. By Richard Mckeon. New York: Randon House, 1941. 


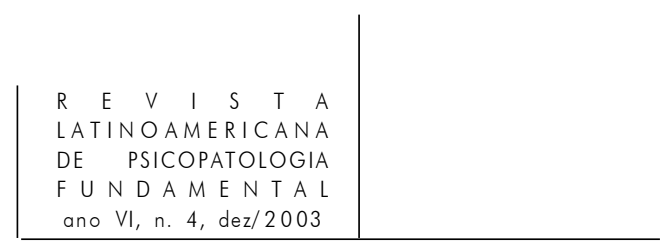

De Saint Exupéry, A. Le Pétit Prince. Paris: Gallimard, 1953.

Figueiredo, L. C. Temporalidad y narratividad em los processos de subjectivación de la clínica psicoanalitica. In: Rovaletti, M. L. (Org.). Temporalidad. El problema del tiempo em el pensamiento actual. Buenos Aires: Lugar Editorial, 1998.

Transferências, contratransferências e outras coisinhas mais, 2002. Texto inédito.

Freud, S. (1912). Ergänzungsband, SA. 164. ESB. Rio de Janeiro: Imago, 1976. v. XII (1915). Zur Dynamik der Übertragung. Studienausgabe. Ergänzungsband. 159-

68. A dinâmica da transferência. ESB. Op. cit. v. XII.

(1920). Jenseits des Lustprinzips, SA. III, 238. Além do princípio do prazer. ESB.

Op. cit. v. XVIII.

(1925). Notiz über den Wunderblock. Studienausgabe. Band III, 363. Uma nota sobre o bloco mágico. ESB. Op. cit. v. XIX.

(1927). Vergänglichkeit. SA. X, 223. Sobre a transitoriedade. ESB. Op. cit. v. XIV.

(1950[1892-1899]). Extratos dos documentos dirigidos a Fliess. ESB. Op. cit. v. I.

Heidegger, M. A questão da técnica (Die Frage nach Technik). Tradução e apresentação de Marco Aurélio Werle. Cadernos de tradução. São Paulo: Departamento de Filosofia da USP, v. 2.

Ser e tempo (Sein und Zeit). Tradução de Maria Márcia Cavalcanti. Petrópolis: Vozes, 1999.

Lógos (Heráclito de Éfeso - Fragmento 50). Tradução de Ernildo Stein. In: $O s$

Pré-socráticos. Coleção Os Pensadores. São Paulo: Abril Cultural, 1973, p. 117-29. Alétheia (Heráclito de Éfeso - 16) Os Pensadores. São Paulo: Abril Cultural, 1973, p. 129-42.

Heráclito de Éfeso. Fragmento 50. Escutando não a mim, mas o Lógos, então é sábio concordar para dizer que Tudo é Um. Tradução de Clémence Ramnoux. Cf. Heráclite ou l' Homme entre les choses et les mots, 1959, p. 220.

Laplanche, J. Du Transfert: sa provocation par l'analyse. In: La Révolution copernicienne inachevée. Travaux 1967-1992. Paris: Aubier, 1992.

Le temps et l'autre. In: La révolution copernicienne inachevée. Op. cit.

Temporalité et traduction - por une remise au travail de la philosophie du temps.

In: La révolution copernicienne inachevée. Op. cit.

Lima, D. O soneto do vôo do cavalo. In: Ideário humanístico (texto datilografado) s/d.

Lloyd, G. E. R. O tempo no pensamento grego. In: Ricoeur, Paul et al. As culturas e o tempo. Estudos reunidos pela Unesco. Introdução de Paul Ricoeur. Tradução de Gentil Titton, Orlando dos Reis e Ephraim Ferreira Alves. Petrópolis: Vozes; São Paulo: Edusp, 1975.

Nunes, B. Heidegger \& Ser e tempo. Rio de Janeiro: Jorge Zahar, 2002. Coleção Passo a Passo.

Paz, O. El arco y la lira. Mexico: Fondo de Cultura Económico, 1990.

Ramnoux, C. Héraclite ou l'homme entre les choses et les mots. Paris: Les Belles Lettres, 1959. 


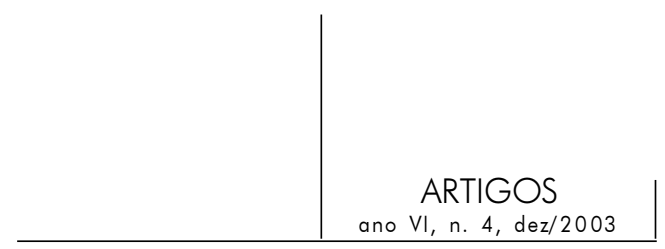

Ricoeur, Paul et al. As culturas e o tempo. Estudos reunidos pela Unesco. Introdução de Paul Ricoeur. Tradução de Gentil Titton, Orlando dos Reis e Ephraim Ferreira Alves. Petrópolis: Vozes; São Paulo: Edusp, 1975.

Rosenfeld, H. K. Palavra pescando não-palavra. A metáfora na interpretação psicanalítica. São Paulo: Casa do Psicólogo, 1998.

Winograd, M. Genealogia do sujeito freudiano. Porto alegre: Artes Médicas, 1998.

\section{Resumos}

El objetivo del artículo es reflexionar sobre la dimensión creativa de la Transferencia en el tiempo del análisis. Para eso, el autor sitúa la temporalidad psicoanalítica en el contexto de la visión filosófica del tiempo y la articula, de modo particular, con la noción de temporalidad defendida por Heidegger en la "Analítica existencial"; después, relaciona la transferencia con la interpretación psicoanalítica, resaltando el poder creativo de la palabra que, por medio de la dialéctica del decir y del escuchar, está en la base de la relación transferencial y contratransferencial vividas en el análisis.

Palabras claves: Transferencia, interpretación analítica, poder creativo de la palabra.

L'objectif de cet article est de réfléchir sur la dimension créative du Transfert dans le Temps de l'analyse. Pour cela, l'auteur situe la temporalité psychanalytique dans le contexte de la vision philosophique du temps et l'articule, d'une façon propre, avec la notion de temporalité proposée par Heidegger dans l'Analytique Existentielle ; ensuite, il lie le Transfert à l'Interprétation Psychanalytique, mettant en exergue le pouvoir créatif de la parole qui, par le biais de la dialectique du dire et de l'écouter, constitue la base de la relation transférentielle et contre-transférentielle vécue dans l'analyse.

Mots clés: Transfert, interprétation analytique et pouvoir créatif de la parole

The objective of this article is to explore the creative dimension of transference. The author places psychoanalytic temporality in the context of a philosophical notion of time and, in particular, in relation to the idea of temporality presented by Heidegger in Existential Analysis. The article then relates transference to analytical interpretation, highlighting the creative power of the word, which, through the dialectical mediation of talking and listening, is at the heart of the transferential relationship experienced during analysis.

Key words: Transference, analytical interpretation, creative power of the word

Versão inicial recebida em janeiro de 2003

Aprovado para publicação em janeiro de 2003 